\title{
Yield and quality of lettuce cultivars irrigated with treated domestic sewage effluent
}

\section{Rendimento e qualidade de cultivares de alface irrigadas com efluente de esgoto doméstico tratado}

\author{
Eric Mateus Soares Dias ${ }^{1}$; Nildo da Silva Dias 2 ; Francisco Vanies \\ da Silva Sá ${ }^{3 *}$; Cleyton dos Santos Fernandes ${ }^{4}$; Daianni Ariane da Costa Ferreira ${ }^{5}$; \\ Jonath Werissimo da Silva Gomes ${ }^{6}$; Isaura Raquel Dantas Fernandes ${ }^{7}$; \\ Francisco Souto de Sousa Junior ${ }^{8}$
}

\begin{abstract}
Given the scarcity of water resources in semi-arid regions and the potential of water reuse as a strategy to solve this problem, this study aimed to evaluate the effects of domestic sewage effluent on growth, yield, and quality of two crisp lettuce cultivars. The research was carried out in greenhouse conditions utilizing an experimental design with randomized blocks in a $5 \times 2$ factorial scheme, with five concentrations from treated domestic effluent blended with tap water $(0,25,50,75$ and $100 \%$ of treated domestic effluent) and two crisp loose lettuce cultivars (Scarlet and Cristal) done in triplicate with five plants per trial. The lettuce plants were growth in trapezoid-shaped PVC channels filled with coconut fiber substrate and organic compost (2:1) for 35 days after transplanting. The experimental results indicated that irrigation with $30 \%$ sewage effluent diluted in tap water gives higher growth and yield of lettuce. The Cristal cultivar shows growth, soluble solids, and chlorophyll higher than the Scarlet cultivar. The application of treated domestic effluent does not affect the post-harvest quality of the lettuce to both cultivars.
\end{abstract}

Key words: Lactuca sativa L. Water resources. Water reuse.

\section{Resumo}

Diante da escassez dos recursos hídricos em regiões semiáridas e do potencial do reuso de água como estratégia de solução desse problema, objetivou-se avaliar os efeitos da aplicação de efluente de

\footnotetext{
${ }^{1}$ Discente de Mestrado, Programa de Pós-Graduação em Estudos Urbanos e Regionais, Universidade Federal do Rio Grande do Norte, UFRN, Campus Natal, Natal, RN, Brasil. E-mail: erickmateus_sd@hotmail.com

2 Prof. Dr., Universidade Federal Rural do Semi-Árido, UFERSA, Campus Mossoró, Mossoró, RN, Brasil. E-mail: nildo@ufersa. edu.br

3 Dr., em Engenharia Agrícola, Programa Nacional de Pós-Doutorado, UFERSA, Campus Mossoró, Mossoró, RN, Brasil. E-mail: vanies_agronomia@hotmail.com

4 Discente de Mestrado, Programa de Pós-Graduação em Manejo de Solo e Água, UFERSA, Campus Mossoró, Mossoró, RN, Brasil. E-mail: cleyton1959@hotmail.com

5 Discente de Doutorado, Programa de Pós-Graduação em Manejo de Solo e Água, UFERSA, Campus Mossoró, Mossoró, RN, Brasil. E-mail: daianniariane@ufersa.edu.br

6 Discente de Doutorado, Programa de Pós-Graduação em Irrigação e Drenagem, Universidade Estadual Paulista, UNESP, Campus Botucatu, Botucatu, SP, Brasil. E-mail: jonathwerissimo@gmail.com

7 M.e em Manejo de Solo e Água, UFERSA, Campus Mossoró, Mossoró, RN, Brasil. E-mail: isa.raquel_2@hotmail.com

8 Prof. Dr., UFERSA, Campus Angicos, Angicos, RN, Brasil. E-mail: franciscosouto@ufersa.edu.br

* Author for correspondence
} 
doméstico tratado no crescimento, produção e qualidade de duas cultivares de alface crespa. A pesquisa foi desenvolvida em ambiente protegido utilizando o delineamento experimental de blocos casualizados em esquema fatorial $5 \times 2$, sendo 5 concentrações do efluente doméstico tratado diluída em água de abastecimento $(0 ; 25 ; 50 ; 75$ e $100 \%$ do efluente doméstico tratado) e 2 cultivares de alface solta crespa (Scarlet e Cristal), com 3 repetições e 5 plantas por repetição. As plantas de alface foram cultivadas em canaletas de PVC tipo trapézio preenchidas com substrato a base de fibra de coco e composto orgânico (2:1), durante 35 dias após o transplantio. Os resultados indicam que a irrigação com efluente doméstico com $30 \%$ água de torneira, conferindo maior crescimento e produção de alface. A cultivar Cristal apresenta maior crescimento e maior teores de sólidos solúveis e clorofila que a cultivar Scarlet. A aplicação do efluente doméstico tratado não afeta a qualidade pós-colheita da alface.

Palavras-chave: Lactuca sativa L. Recursos hídricos. Reuso de água.

\section{Introduction}

The water crisis is a worldwide challenge requiring the use of technologies that allow the efficient use and enhancement of water resources. This is especially true in the agricultural sector which is responsible for most water catchment (WHATELY, CAMPANELY, 2016). In this context, there is a need to reuse water resources and, at the same time, consider the cost/benefit ratio that meets the applicable legislation to mitigate environmental impacts (RODRIGUES et al., 2011; ALVES et al., 2014).

Adequate management of water resources is an issue frequently addressed in the international scientific community and specifically in Brazil. Despite extensive territorial water reserves, there are problems of scarcity in some Brazilian regions, notably semi-arid ones. Thus, the use of wastewater in agriculture has aroused great interest, demonstrating significant growth in recent years (BAIONI et al., 2017).

The use of treated sewage effluents is not a new practice; however, there is a growing interest in the need to reuse it, especially in agriculture (ALBUQUERQUE JUNIOR et al., 2016). The interest in using treated wastewater in irrigation is the subject of more recent studies (RODRIGUES et al., 2011; OLIVEIRA et al., 2012; JUCHEN et al., 2013; ALVES et al., 2014; CUBA et al., 2015; ALBUQUERQUE JUNIOR et al., 2016; BAIONI et al., 2017). It has become an attractive option since it reduces contamination by direct discharge of sewage in the water bodies, improves the potability conditions, allows a more rational use of resources, and is an alternative source of available water for agricultural crops. (MARTÍNEZ et al., 2013; CUBA et al., 2015). However, the effects of crop fertilization using treated sewage effluents should be monitored to ensure that they do not compromise the final product quality or consumer acceptance (ALVES et al., 2017).

Lettuce (Lactuca sativa L.) is one of the most consumed vegetables in Brazil and can be grown all year long with varieties adapted to the climate of each region (SALA, COSTA, 2012). There are several groups of lettuce in the world; however, in Brazil, the best known and consumed lettuces are curly and smooth (HENZ; SUINAGA, 2009).

Lettuce cultivation in Brazil has as its main problem the scarcity of water resources, primarily in the semi-arid regions, which has been the focus of numerous researches mainly aimed at incorporating the use of wastewater to increase water availability for crop production (RODRIGUES et al., 2011; JUCHEN et al., 2013; CUBA et al., 2015; ALBUQUERQUE JUNIOR et al., 2016). Another condition related to the quality of lettuce production is nutritional requirements. According to Meirelles et al. (2017), due to its short cultivation cycle, lettuce is a very demanding crop in nutrients, and the deficiency of these nutrients present symptoms that can be identified visually as abnormal color, growth, burning, and distortions of parts of the plant. Thus, besides acting as a water source, 
treated domestic sewage presents properties of a biofertilizer (REBOUÇAS et al., 2010) which can provide mineral nutrition to the crop.

On the other hand, although the literature confirms that domestic sewage effluent can effectively increase the availability of water resources for irrigation, there is a need for continuous monitoring of concentrations of potentially toxic elements in soil, plants, and groundwater. However, in order to avoid accumulation of these elements in the soil, hydroponic cropping systems using crop substrates may be a viable method to prevent the impact of effluent disposal on the soil, since in these systems there is a control of the application of sewage effluents. These systems also make possible the recycling of substrates enriched with nutrients for use in successive cycles.

In view of the above, this study was aimed to evaluate the effects of treated sewage effluent on the growth, production, and quality of two cultivars of curly lettuce.

\section{Material and Methods}

The research was conducted in a greenhouse at the Department of Environmental and Technological Sciences located in the West Campus of the Universidade Federal Rural do Semiárido (UFERSA) in Mossoró/RN ( $5^{\circ} 11^{\prime}$ south latitude, $37^{\circ} 20^{\prime}$ longitude W. Gr., and $18 \mathrm{~m}$ of altitude) during the period between April and May 2016.

A randomized complete block design was used in a $5 \times 2$ factorial scheme, with 5 concentrations of the treated domestic effluent diluted in the supply water $(0,25,50,75$ and $100 \%$ of the treated domestic effluent) and two cultivars of loose curly lettuce (C1 - Scarlet and C2 - Crystal), with three replicates and five plants per replicate.

The lettuce plants were cultivated in trapezoidshaped PVC channels filled with substrate based on coconut fiber and organic compost HortVida ${ }^{\circledR}$ $(2: 1)$. The organic compost had the following characteristics: $13 \%$ (weight/weight) nitrogen (N), 50\% (weight/weight) moisture, 21\% (weight/ weight) organic carbon (C), cation exchange capacity (CEC) of $371 \mathrm{mmol}_{\mathrm{c}} \mathrm{dm}^{-3}, \mathrm{C} / \mathrm{N}$ ratio of 15.8, $\mathrm{CEC} / \mathrm{C}$ ratio of 17.6, and a $\mathrm{pH}$ of 6.0. The material was manually mixed in a 500 L PVC box, measured proportionally with $7 \mathrm{~L}$ buckets using two parts coconut fiber to one part organic compost. Then, the trapezoid PVC channels with a $3 \mathrm{~m}$ length were filled manually and placed $0.90 \mathrm{~m}$ from the soil level of the protected environment. They had perforations at their base every $0.5 \mathrm{~m}$ to drain the excess solution and were fixed with a wood support with declivity of approximately $3 \%$ to facilitate the drainage of excess irrigation water. The substrate was irrigated with supply water daily over a period of seven days until the transplant of the seedlings.

The system adopted was drip irrigation, where irrigations were done daily at the end of the afternoon using $0.5 \mathrm{~m}$ spaced emitters, $2.5 \mathrm{~L} \mathrm{~h}^{-1}$ water flow, and five reservoirs with a capacity of $250 \mathrm{~L}$ each. The supply water used in the experiment comes from the UFERSA well. The chemical characteristics come from the Companhia de Águas e Esgotos do Rio Grande do Norte (CAERN) [Water and Sewage Company of Rio Grande do Norte] (Table 1).

Table 1. Chemical characterization of water sources used for irrigation.

\begin{tabular}{ccccccccccc}
\hline \multirow{2}{*}{ Source } & $\mathrm{EC}\left(\mathrm{dS} \mathrm{m}^{-1}\right)$ & $\mathrm{pH}$ & & $\mathrm{Ca}^{2+}$ & $\mathrm{Mg}^{2+}$ & $\mathrm{Na}^{+}$ & $\mathrm{Cl}^{-}$ & $\mathrm{CO}_{3}^{2-}$ & $\mathrm{HCO}^{3-}$ & \multicolumn{2}{c}{$\mathrm{SAR}$} \\
\cline { 5 - 10 } WS & 0.55 & 7.5 & 1.0 & 0.9 & 4.44 & 2.4 & 0.7 & 3.4 & $\mathrm{molc} \mathrm{L}^{-1}$ \\
\hline
\end{tabular}

$\mathrm{WS}=$ water supply; $\mathrm{EC}=$ Electrical conductivity; $\mathrm{pH}=$ Potential of hydrogen $\mathrm{Ca}^{2+}=$ Calcium; $\mathrm{Mg}^{2+}=\mathrm{Magnesium} ; \mathrm{Na}^{+}=\mathrm{Sodium}$; $\mathrm{Cl}=$ Chloride; $\mathrm{CO}_{3}^{2-}=$ Carbonate; $\mathrm{HCO}_{3}=$ Bicarbonate; $\mathrm{SAR}=$ Sodium adsorption ratio. 
The domestic sewage effluent was collected from a low-cost gray water treatment system installed for primary treatment at the headquarters of the Community Association Recycling for Life (ACREVI). The system consists of a masonry grease box with $0.40 \times 0.40 \times 0.40 \mathrm{~m}$, two septic tanks with a capacity of $1000 \mathrm{~L}$, a $1000 \mathrm{~L}$ anaerobic filter and a 100 $\mathrm{L}$ tank to store treated water (FERNANDES, 2017).

The analysis of treated domestic sewage effluent showed that the treatment is efficient in removing most of the biochemical and microbiological parameters with potential to harm human health, with all values being within the limits allowed by the irrigation water legislation (CONAMA, 2008).
For the physico-chemical and microbiological characterization (Table 2), samples were collected and preserved in isothermal boxes with ice at $4{ }^{\circ} \mathrm{C}$ until they entered the laboratories. The physico-chemical analysis was performed at the Laboratório de Análise de Solo, Água e Planta - LASAP (Laboratory of Analysis of Soil, Water and Plant) at UFERSA, while the microbiological analysis was performed at the HIDROLAB Laboratory - Central Hidrolab Serviços LTDA. The identification and quantification of the total and thermotolerant coliforms population levels was based on the methods proposed by the "Standard methods for the examination of water and wastewater" (RICE et al., 2012).

Table 2. Physical-chemical and qualitative characterization of the wastewater produced in ACREVI.

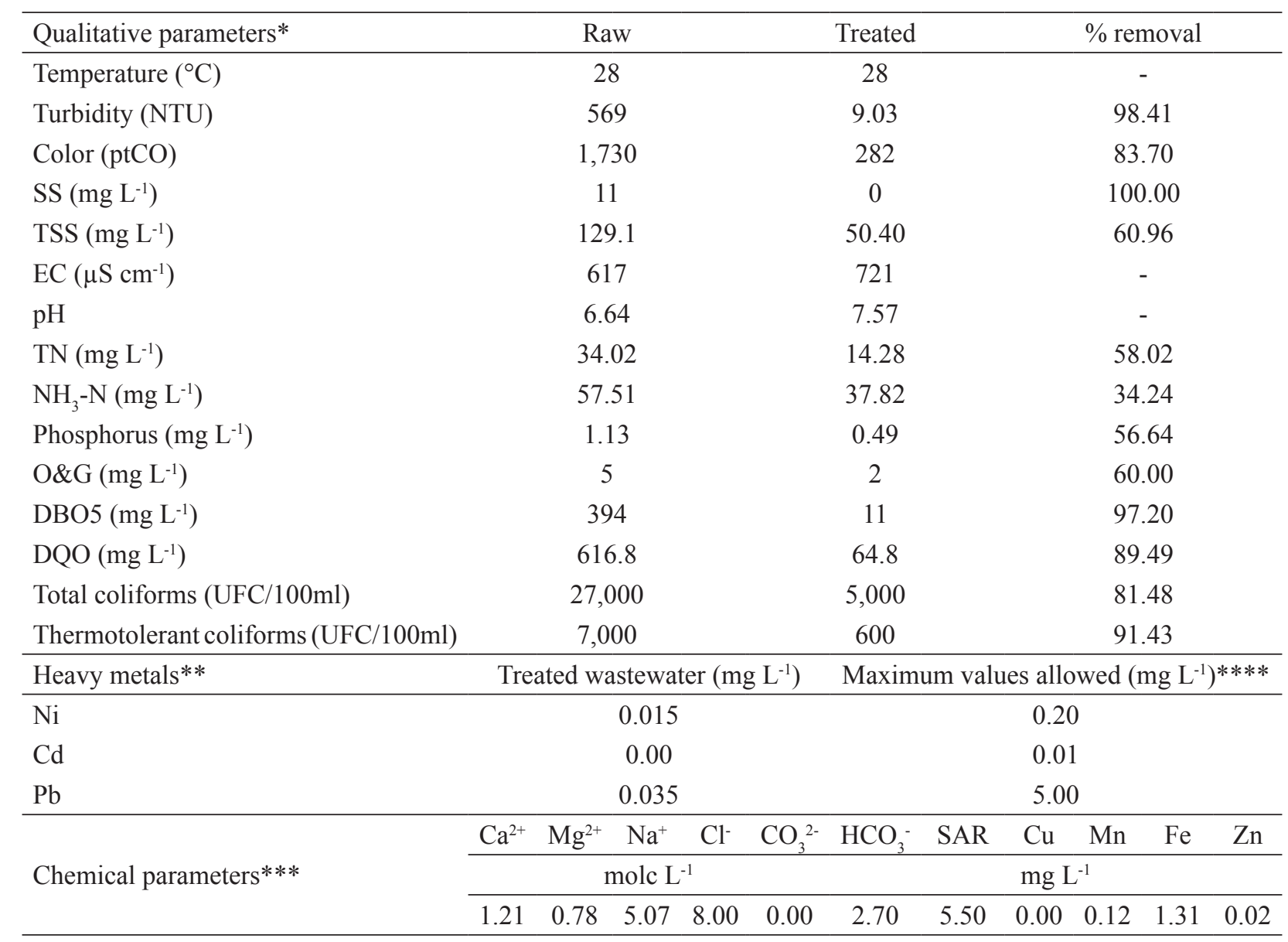

*SS = Sedimentable solids; TSS = Total suspended solids; EC = Electrical conductivity; $\mathrm{pH}=$ Potential of hydrogen; TN = Total Nitrogen; $\mathrm{NH}_{3-} \mathrm{N}=$ Ammoniacal nitrogen; O\&G = Oils and Greases; $\mathrm{BOD}=$ Biochemical oxygen demand; COD = Chemical oxygen demand; $\mathrm{CFU}=$ Colony forming unit.

$* * \mathrm{Ni}=$ Nickel; $\mathrm{Cd}=$ Cadmium; $\mathrm{Pb}=$ Lead.

$* * * \mathrm{Ca}^{2+}=$ Calcium; $\mathrm{Mg}^{2+}=$ Magnesium; $\mathrm{Na}+=$ Sodium; $\mathrm{Cl}-=$ Chloride; $\mathrm{CO}_{3}{ }^{2-}=$ Carbonate $\mathrm{HCO}_{3}{ }^{-}=$Bicarbonate; $\mathrm{SAR}=\mathrm{Sodium}$ adsorption ratio; $\mathrm{Cu}=$ Copper; $\mathrm{Mn}=$ Manganese; $\mathrm{Fe}=$ Iron; $\mathrm{Zn}=$ Zinc.

**** CONAMA (2008). 
The seeds of both lettuce cultivars were produced on March 7, 2017 in expanded polystyrene trays of 200 cells filled with substrate composed of organic fertilizer by the organic company HortVida ${ }^{\circledR}$. These were transplanted 25 days after sowing - DAS alternately in the channels, spacing $30 \mathrm{~cm}$ between plants.

Harvesting occurred 35 days after transplanting (DAT). The plants were collected to determine the following: number of leaves (NL) by counting the number of leaves, starting from the basal leaf until the last opening leaf; height of the plant (HP) determined from the ground to the highest part of the plant, obtained with a graduated ruler; leaf area (LA) by measuring the length $(\mathrm{cm})$ and width $(\mathrm{cm})$, obtained through a ratio of length $\mathrm{x}$ height $\mathrm{x}$ number of leaves; shoot fresh mass (SFM) and fresh mass of the root (FMR), through collection, sectioning, packing the plants in paper bags, and weighing on an electronic scale with accuracy of 0.01g; shoot dry mass (SDM) and dry mass of the root (DMR), where the samples were placed in an oven at $65{ }^{\circ} \mathrm{C}$ with forced air circulation until they reached constant weight and were later weighed in an analytical balance with an accuracy of $0.0001 \mathrm{~g}$.

The plants were also evaluated post-harvest determining the following: soluble solids - SS (\%), determined directly in the homogenized juice, through a digital refractometer reading (SAMMAR model 852610472); titratable Acidity - TA (\% citric acid) determined by titration using a $1.0 \mathrm{~mL}$ aliquot of juice to which $49.0 \mathrm{~mL}$ of distilled water and 3 drops of $1 \%$ alcoholic phenolphthalein are added using 0.1 $\mathrm{N}$ sodium hydroxide solution $(\mathrm{NaOH})$ standardized with potassium biftalate as titrant (IAL, 2008); potential of hydrogen $(\mathrm{pH})$, determined in Tecnopon brand pHmeter (Model mPA - 210P / Version 7.1), with direct electrode insertion according to IAL
(2008); Vitamin C (mg.100 $\mathrm{mL}^{-1}$ of Ascorbic Acid), determined according to AOAC (2005) through titration with 2.6 dichlorophenolindofenol (DFI) until obtaining permanent clear pink staining, using $1.0 \mathrm{~mL}$ of diluted juice in $49.0 \mathrm{~mL}$ of oxalic acid $0.5 \%$. Chlorophyll content $\left(\mathrm{mg} \mathrm{cm} \mathrm{cm}^{-2}\right)$ was determined according to the laboratory method developed by Lichtenthaler (1987), using samples of five discs from the limb of the third mature leaf from the apex. From the extracts, the concentration of chlorophyll in the solutions was determined by the spectrophotometer at absorbance wavelength A (470, 646.8 and $663.2 \mathrm{~nm}$ ) using Equation 1 below.

Total Chlorophyll $\left(\mathrm{mg} \mathrm{cm}^{-2}\right)=17.3 \mathrm{~A} 646+7.18$ A663 (1)

The data were submitted to analysis of variance ' $F$ ' test, in case of isolated significance of the ' $t$ ', Student's cultivars, isolated significance of the effluent concentrations, or the interaction between the factors. A polynomial regression analysis was performed at the $5 \%$ probability level using the statistical software SISVAR ${ }^{\circledR}$ (FERREIRA, 2014).

\section{Results and Discussion}

A significant interaction $(\mathrm{p}<0.05)$ was observed between the concentrations of treated domestic effluent and lettuce cultivars for leaf area. For the variables plant height, leaf number, shoot fresh and root, shoot dry mass and root, and chlorophyll contents was observed a significant difference ( $p$ $<0.05$ ) isolated from the concentrations of treated domestic effluent. Among cultivars, a significant difference $(p<0.05)$ was observed for leaf number, soluble solids content and chlorophyll content. For variables: titratable acidity, potential of hydrogen, and vitamin $\mathrm{C}$ were not verified influence of the factors tested (Table 3). 
Table 3. Summary of the 'F' test for the variables: Height of the plant (HP), number of leaves (NL), leaf area (LA), shoot fresh mass (SFM) and root (FMR), shoot dry mass (SDM) e root (DMR), total soluble solids (TSS), titratable acidity (TA), potential of hydrogen (pH), vitamin C (Vit C) and chlorophyll (CHLO) on leaves of lettuce cultivars cultivated on coconut fiber substrate under increasing doses of treated domestic sewage at 35 days after transplanting.

\begin{tabular}{|c|c|c|c|c|c|c|c|}
\hline \multicolumn{8}{|c|}{ Summary of the ' $F$ ' test } \\
\hline SV & $\mathrm{DF}$ & HP & NL & LA & SFM & FMR & SDM \\
\hline Blocks & 2 & NS & NS & NS & NS & NS & NS \\
\hline Effluent (E) & 4 & $*$ & $*$ & $*$ & $*$ & $*$ & * \\
\hline Cultivar (C) & 1 & NS & * & $*$ & NS & NS & NS \\
\hline $\mathrm{E} \times \mathrm{C}$ & 4 & NS & NS & * & NS & NS & NS \\
\hline Error & 18 & - & - & - & - & - & - \\
\hline CV (\%) & & 12.58 & 11.14 & 14.70 & 32.01 & 17.20 & 19.23 \\
\hline Overall mean & & 18.58 & 18.75 & 161.48 & 196.31 & 77.21 & 14.92 \\
\hline \multicolumn{8}{|c|}{ Summary of the 'F' test } \\
\hline SV & DF & DMR & SS & TA & $\mathrm{pH}$ & Vit $\mathrm{C}$ & CHLO \\
\hline Blocks & 2 & NS & NS & NS & NS & NS & $*$ \\
\hline Effluent (E) & 4 & $*$ & NS & NS & NS & NS & * \\
\hline Cultivar (C) & 1 & NS & * & NS & NS & NS & * \\
\hline $\mathrm{E} \times \mathrm{C}$ & 4 & NS & NS & NS & NS & NS & NS \\
\hline Error & 18 & - & - & - & - & - & - \\
\hline CV (\%) & & 20.68 & 12.49 & 7.31 & 2.48 & 9.31 & 15.75 \\
\hline Overall mean & & 11.25 & 3.93 & 0.14 & 6.08 & 0.21 & 0.32 \\
\hline
\end{tabular}

* and ${ }^{N S}$ : significant at 5\% probability and not significant, respectively, by test F. SV= Source of variation; DF $=$ Degrees of freedom; $\mathrm{CV}=$ Coefficient of variation.

The height and number of leaves from lettuce plants presented quadratic behavior as a function of the increase of the domestic effluent concentration in the irrigation water, with the highest values (21.04 $\mathrm{cm}$ and 22 leaves) observed at concentrations of 83.8 and $76.03 \%$, respectively (Figures 1A and 1B). At levels higher than this, a reduction in the height and number of leaves of the plants was observed. This also affects the accumulation of biomass, indicating that high concentrations of treated domestic effluent can exert toxicity effects on plants due to excess nutrients (mainly nitrogen) as observed in pepper and okra plants by Oliveira et al. (2012) and ornamental sunflower by Alves et al. (2014). Regarding the cultivars, it was verified that the highest number of leaves were emitted by the cultivar Cristal, with $17.58 \%$ higher emission than the Scarlet leaves, indicating a higher growth potential of this cultivar (Figure 1C).
As observed for plant height and number of leaves, the Scarlet (C1) cultivar also presented a quadratic behavior for leaf area as a function of the concentration of sewage effluent in the irrigation solution, with the highest leaf area $\left(204.47 \mathrm{~cm}^{2}\right)$ observed at an application of $63.78 \%$ effluent (Figure 1D). However, the leaf area of the cultivar Cristal (C2) responded linearly to the increase in the concentration of treated domestic effluent, with increases of $1.38 \mathrm{~cm}^{2}$ for each unit increase of the percentage of effluent in the irrigation solution (Figure 1D). Increased concentration of treated domestic effluent has benefits in the growth of lettuce plants, with 352 and $286 \%$ increments, respectively, in the leaf area of the cultivars Scarlet and Cristal, comparing the results of the concentration of $63.78 \%$ and $100 \%$ to the concentration $0 \%$ water supply control (Figure 1D). Promising results from the application of wastewater from domestic sewage on 
plant growth were also observed in watermelon and tomato by Costa et al. (2013) and in pepper and okra by Oliveira et al. (2012). According to Andrade et al. (2014), the greatest growth in plant height when irrigated with wastewater may be associated, mainly, with the positive effect of the nitrogen present in the water on the vegetative growth of the plants, since in the water supply this important growth element is usually absent.

The increase of the concentration of treated domestic effluent influenced the biomass accumulation of the lettuce plants, with quadratic behavior being seen for the variables shoot fresh mass and root, shoot dry mass and root. Greater accumulation of biomass of $263.61 \mathrm{~g}$ of shoot fresh matter, $89.18 \mathrm{~g}$ of fresh matter of the root, $19.30 \mathrm{~g}$ of shoot dry matter, and $12.46 \mathrm{~g}$ of dry matter of the root was observed in plants irrigated with solutions containing $60.76,74.45,65.51$, and $88.75 \%$ of effluent, respectively (Figure 2A, B, C and D). According to Rodrigues et al. (2011). The positive effects on the average lettuce yield provided by fertirrigation with wastewater demonstrate that the use of these inferior waters as a source of nutrients in vegetables should continue to be investigated.

Figure 1. Height of the Plant, HP (A), Number of Leaves, NL (B e C) e Leaf Area, LA (D) of cultivars of curly lettuce $\left(\diamond \mathrm{C}_{1}-\right.$ Scarlet and $\mathbf{m C}_{2}-$ Cristal) cultivated on coconut fiber substrate under increasing doses of wastewater from treated domestic sewage at 35 days after transplanting.

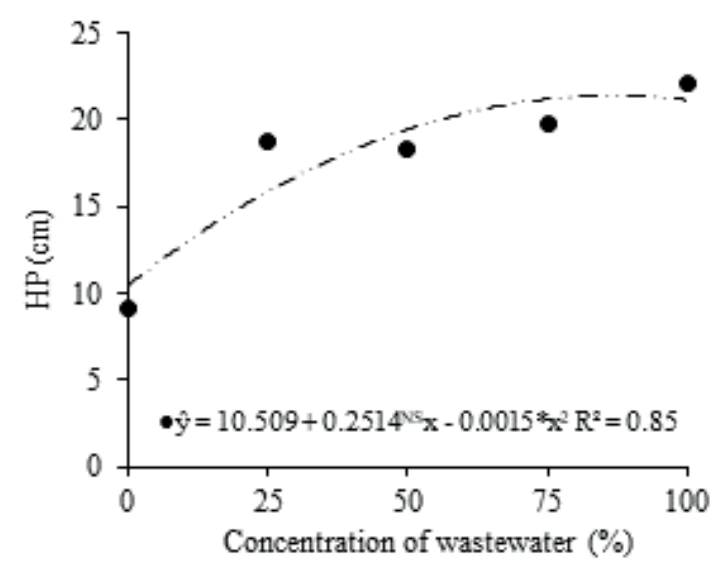

$\mathrm{C}$

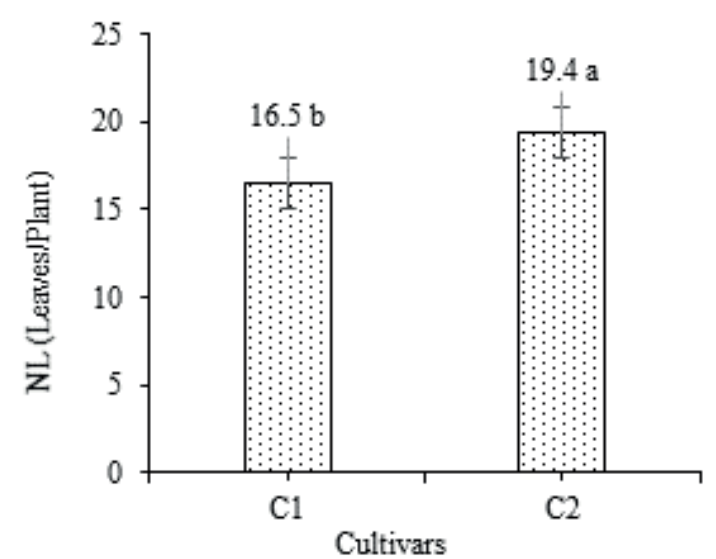

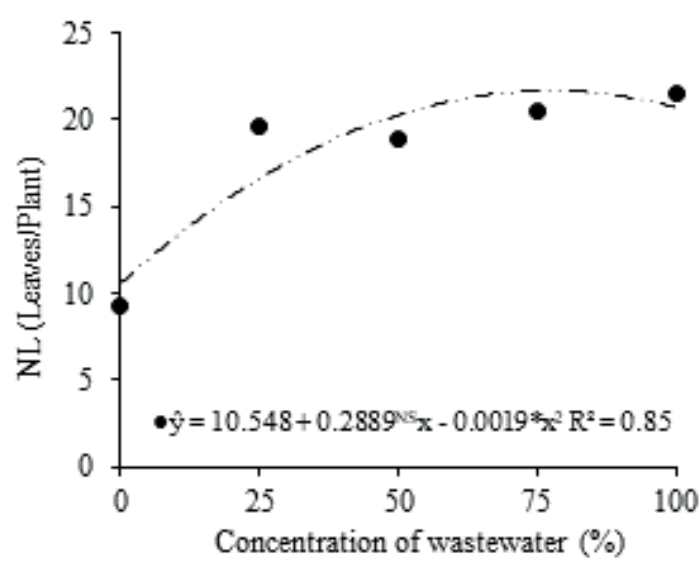

$\mathrm{D}$

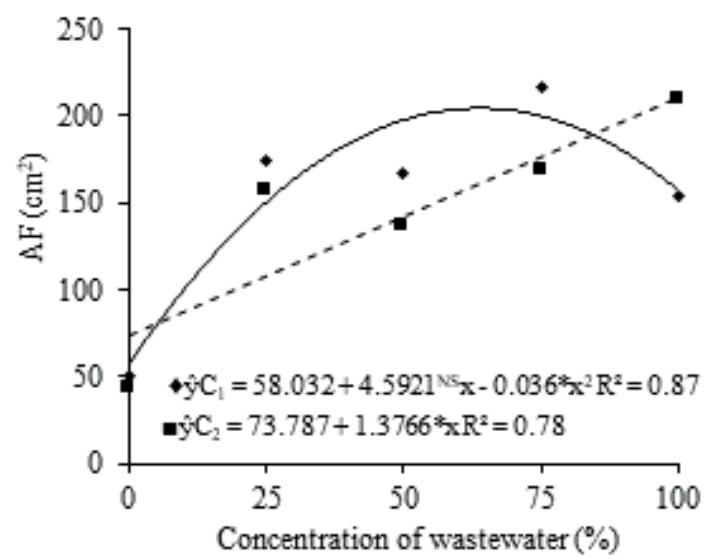

* and NS $=$ significant at $5 \%$ probability and not significant, respectively. Means followed by the same letter do not differ significantly at the $5 \%$ level ('t' of Student test). 
Figure 2. Shoot fresh mass, SFM (A) and root, FMR (B), shoot dry mass, SDM (C) and root, DMR (D) of cultivars of curly lettuce $\left(\mathrm{C}_{1}-\right.$ Scarlet and $\mathrm{C}_{2}-$ Cristal $)$ cultivated on coconut fiber substrate under increasing doses of wastewater from treated domestic sewage at 35 days after transplanting.

A

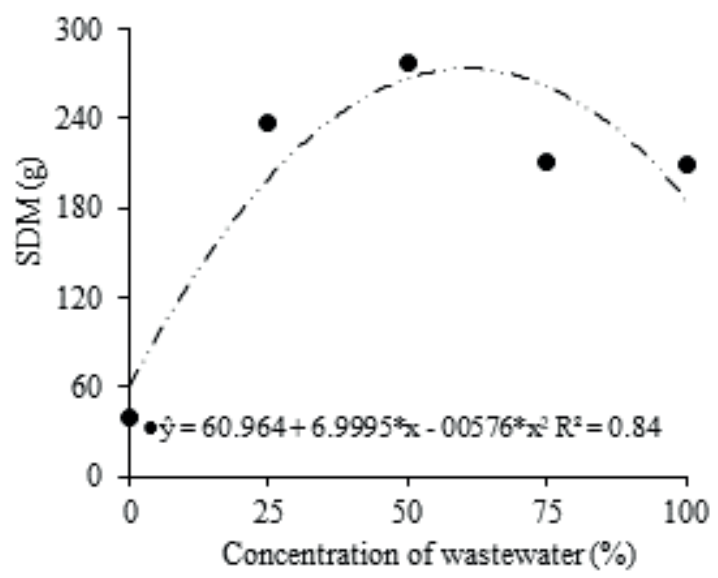

$\mathrm{C}$

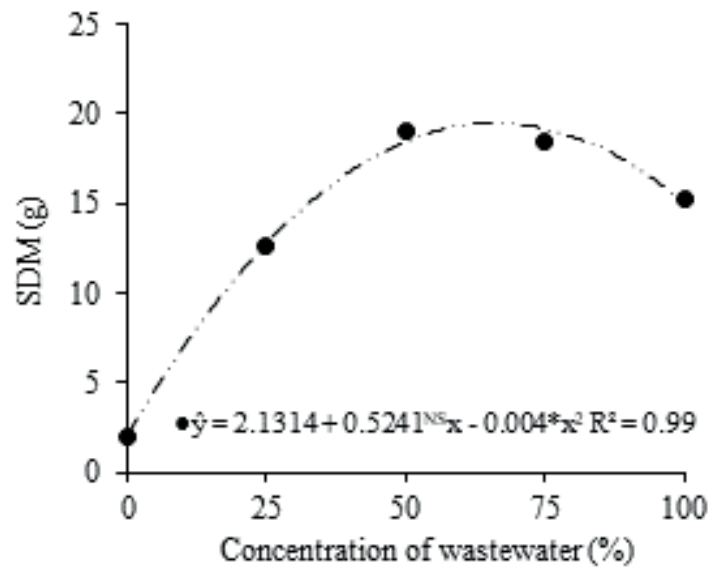

B

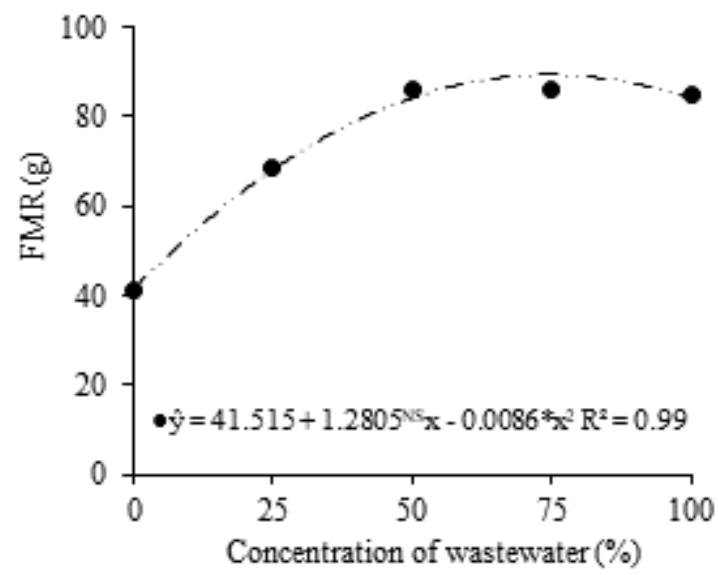

$\mathrm{D}$

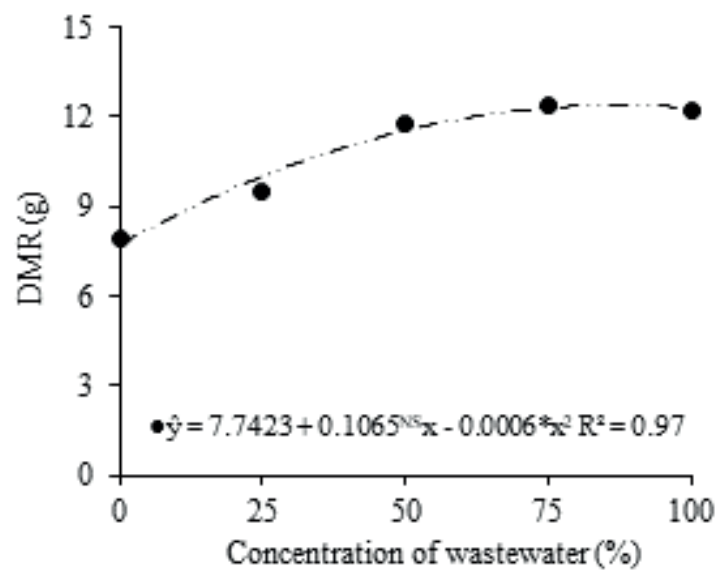

* and NS $=$ significant at $5 \%$ probability and not significant, respectively. Means followed by the same letter do not differ significantly at the $5 \%$ level (' $t$ ' of Student test).

The results obtained in this work for the production of shoot fresh matter are twice as high as the $118.57 \mathrm{~g}$ of shoot fresh mass of the observed by Cuba et al. (2015) while evaluating the use of domestic wastewater treated in the production of curly lettuce cv. Vanda. The results obtained in the present research for dry matter are in agreement with those observed by Rodrigues et al. (2011) working with dairy wastewater and fridge in the cultivation of American lettuce cv. Tainá.
Regarding the increment of root dry mass observed in this work as a function of the increasing doses of treated domestic effluent, Andrade et al. (2014) state that it is possibly related to the phosphorous content in the wastewater, because that nutrient favors the development of the root system.

In the present study, the use of treated domestic effluent allowed the satisfactory production of lettuce grown on coconut fiber substrates, even in the absence of chemical fertilization. It was 
confirmed that the use of the effluent, in addition to supplying the water needs of the crop, can act as a biofertilizer providing satisfactory yield at low cost. This was also postulated by Rebouças et al. (2010). According to Juchen et al. (2013), the availability of nutrients (mainly nitrogen) from organic fertilizers are fundamental to the growth and development of plants and may explain the satisfactory productivity achieved by fertirrigated plants with wastewater. This fact is very important for family farming, since some wastewater does not have the characteristic of supplying the nutritional needs of the crops, as observed by Baioni et al. (2017). The authors verified that in order to obtain satisfactory production of the coriander and chives cultures it is necessary to associate fishery wastewater with chemical fertilization.

In relation to the post-harvest quality, there were higher levels of soluble solids and chlorophyll content in the cultivar Cristal (C2), being 13.68 and $75.0 \%$ higher in relation to Scarlet (C1), respectively (Figures $1 \mathrm{~A}$ and $\mathrm{B}$ ). These results indicate that the cultivar Cristal has a higher quality than the Scarlet cultivar (Figure 1D), and that the highest concentration of chlorophyll is indicative of higher concentrations of nitrogen and probably higher photosynthetic potential and synthesis of carbohydrates. That may have contributed to the higher concentration of soluble solids, which could confer a greater degree of sweetness on the leaves of the plants of this cultivar.

The chlorophyll content was also influenced by the increased concentration of the treated domestic effluent, and a quadratic response was verified with the highest chlorophyll index $0.39 \mathrm{mg} \mathrm{\textrm {cm } ^ { 2 }}$ being observed when $68.75 \%$ of the effluent was used in the irrigation water (Figure 3C). The increase in chlorophyll content coincides with an increase in shoot biomass gain, as well as losses caused by the use of effluent concentrations higher than $70 \%$ (Figures 2A and 3C). This indicates that concentrated effluent application exerts a cytotoxic effect on lettuce plants, compromising the biomass gain and the synthesis of biomolecules such as chlorophyll, due to the high concentration of nutrients (mainly nitrogen). These results indicate the importance of studies related to the management of wastewater application associated with agricultural crops, given that studies carried out by Juchen et al. (2013) evaluating the biomass production of lettuce cv. Tainá did not find a negative influence of the application of $100 \%$ of refrigerated and dairy water on the plants. However, Fonteles et al. (2015) evaluating the use of wastewater from domestic sewage treated in the cultivation of lettuce cv. Babá de Verão, found reductions in growth and biomass accumulation in concentrations higher than $50 \%$ of the effluent.

Although no changes were observed in titratable acidity, potential of hydrogen, and vitamin $\mathrm{C}$ content, mean values of $0.14 \%$ of citric acid, 6.08 unit and $0.21 \mathrm{mg} 100 \mathrm{~mL}^{-1}$ of ascorbic acid, as well as the soluble solids content of $3.93^{\circ}$ Brix (Table 3 ), those attributes are within the range observed for the agricultural culture by Reis et al. (2014) and Nascimento et al. (2017) evaluating post-harvest quality of lettuce cv. Isabel and Julia in organic and conventional cultivation, respectively. These results indicate that the application of the treated domestic effluent can be used without compromising the post-harvest quality of lettuce. 
Figure 3. Soluble solids, SS (A) and chlorophyll, CHLO (B and C) on leaves of cultivars of curly lettuce $\left(\mathrm{C}_{1}-\right.$ Scarlet $\mathrm{e}_{2}$ - Cristal) cultivated on coconut fiber substrate under increasing doses of wastewater from treated domestic sewage at 35 days after transplanting.

A

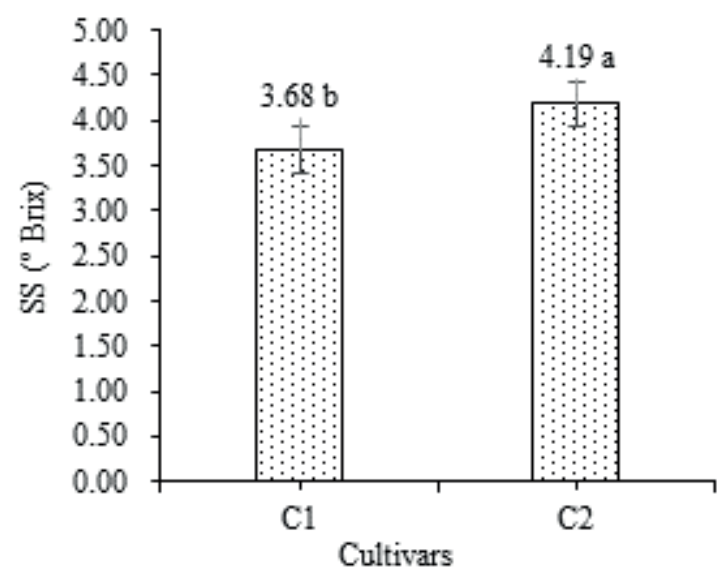

$\mathrm{B}$

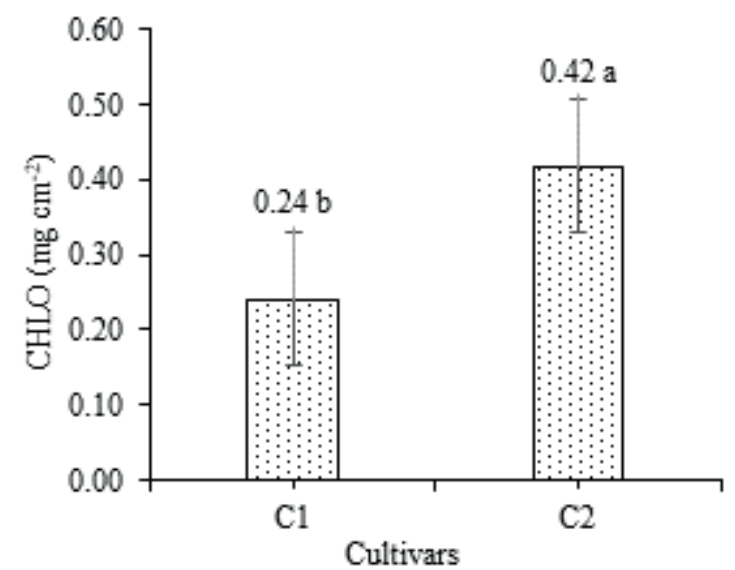

$\mathrm{C}$

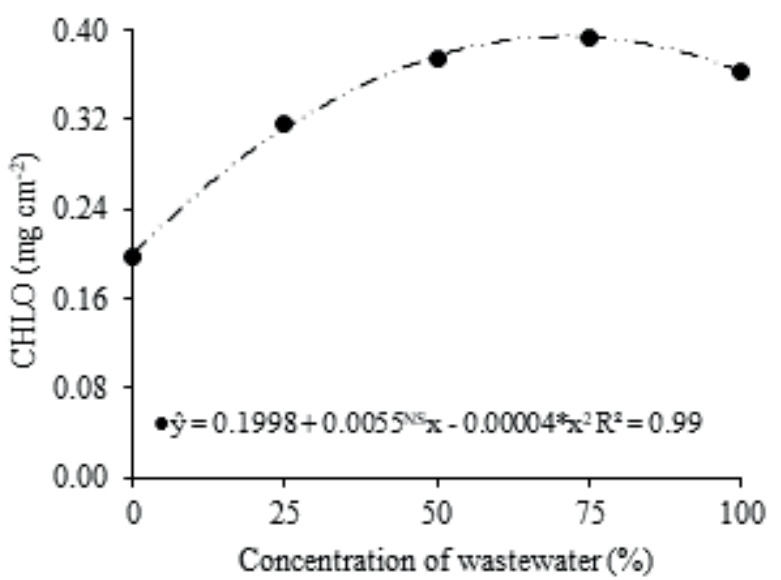

$*$ and NS $=$ significant at $5 \%$ probability and not significant, respectively. Means followed by the same letter do not differ significantly at the $5 \%$ level ('t' of Student test)

\section{Conclusions}

The treated domestic effluent can be used as irrigation water for lettuce cultivation, with a recommended concentration of $70 \%$ giving greater growth and production.

The cultivar Cristal presents higher growth, higher content of soluble solids, and higher chlorophyll content than the cultivar Scarlet.

The different proportions of sewage effluent in irrigation water did not interfere in the post-harvest quality of lettuce.

\section{References}

ALBUQUERQUE JÚNIOR, J. E.; AZEVEDO, C. A. V.; AZEVEDO, M. R. Q. A.; XAVIER, J. F.; MONTEIRO FILHO, A. F. Qualidade de águas residuária e salobra utilizadas no cultivo hidropônico de três cultivares de alface crespa. Revista Verde de Agroecologia e Desenvolvimento Sustentável, Pombal, v. 11, n. 2, p. 1924, 2016. DOI: $10.18378 /$ rvads.v11i2.4569

ALVES, P. F. S.; SANTOS, S. R.; KONDO, M. K.; MIZOBUTSI, G. P.; CALDEIRA, L. A.; ALVES, I. S.; ANTUNES, A. B.; OLIVEIRA, G. F. Banana fertigation with treated sanitary wastewater: postharves and microbiological quality. Semina: Ciências Agrárias, 
Londrina, v. 38, n. 3, p. 1229-1240, 2017. DOI: $10.5433 / 1679-0359.2017 \mathrm{v} 38 \mathrm{n} 3 \mathrm{p} 1229$

ALVES, S. M. C.; REBOUÇAS, J. R. L.; FERREIRA NETO, M.; BATISTA, R. O.; SOUZA, L. Fertirrigação de girassol ornamental com esgoto doméstico tratado em sistema de hidroponia. Irriga, Botucatu, v. 19, n. 4, p. 714-726, 2014.

ANDRADE, L. O.; GHEYI, H. R.; NOBRE, R. G.; DIAS, N. S.; NASCIMENTO, E. C. S. Crescimento de girassóis ornamental em sistema de produção orgânica e irrigada com água residuária tratada. Irriga, Botucatu, v. 1, p. 69-82, 2014. Edição Especial. DOI: 10.15809/ irriga.2012v1n01p69

ASSOCIATION OF OFFICIAL ANALYTICAL CHEMISTS - AOAC. Official methods of analysis of the association analytical chemists. 18. ed. Gaithersburg: Maryland, 2005. 1015 p.

BAIONI, J. C.; SQUASSONI, G. H.; CULTRI, G. R. S.; SILVA, J. D. T.; DIAS, L. T. S. Efluente de piscicultura na produção consorciada de cebolinha e coentro. Nucleus Animalium, Ituverava, v. 9, n. 1, p. 143-150, 2017. DOI: 10.15809/irriga.2012v1n01p69

CONSELHO NACIONAL DE MEIO AMBIENTE. - CONAMA. Resoluções CNRH $n^{\circ}$ 54, de 28 de novembro de 2005, e $n^{\circ} X X$, de 27 de março de 2008. Disponível em: <http://www.mma.gov.br/ port/conama/ processos/838F10BD/PropRecom PadraoAguaReuso_27mar081.pdf $>$. Acesso em: $10 \mathrm{de}$ nov. 2017.

COSTA, M. S.; ALVES, S. M. C.; FERREIRA NETO, M.; BATISTA, R. O.; TORRES, S. B. Avaliação do desempenho de melancia e tomate cereja sob tratamento com efluente doméstico. Engenharia Ambiental, Espírito Santo do Pinhal, v. 10, p. 66-74, 2013. Suplemento.

CUBA, R. S.; CARMO, J. R.; SOUZA, C. F.; BASTOS, R. G. Potencial de efluente de esgoto doméstico tratado como fonte de água e nutrientes no cultivo hidropônico de alface. Revista Ambiente \& Água, Taubaté, v. 10, n. 3, p. 574-586, 2015. DOI: 10.4136/ambi-agua. 1575

FERNANDES, I. R. D. Tratamento de água cinza e sua aplicação na fertirrigação do girassol ornamental. 2017. Dissertação (Mestrado) - Universidade Federal Rural do Semi-Árido, Mossoró.

FERREIRA, D. F. Sisvar: a Guide for its Bootstrap procedures in multiple comparisons. Ciência $e$ Agrotecnologia, Lavras, v. 38, n. 2, p. 109-112, 2014. DOI: $10.1590 / \mathrm{S} 1413-70542014000200001$

FONTELES, J. L. V.; MOURA, K. K. C. F.; DIAS, N. S.; CARNEIRO, J. V.; GUEDES, R. A. A. Crescimento e produção de duas cultivares de alface utilizando água de esgoto tratado. Revista Brasileira de Agricultura Irrigada, Fortaleza, v. 9, n. 5, p. 320-325, 2015. DOI: 10.7127/RBAI.V9N500322

HENZ, G. P.; SUINAGA, F. A. Tipos de alface cultivados no Brasil. Brasília, DF: Embrapa Hortaliças, 2009. 7 p. (Embrapa Hortaliças. Comunicado técnico, 75).

INSTITUTO ADOLFO LUTZ - IAL Métodos físicoquímicos para análise de alimentos. 4. ed. São Paulo: IAL, 2008. 1018 p.

JUCHEN, C. R.; SUSZEK, F. L.; BOAS, M. A. V. Irrigação por gotejamento para produção de alface fertirrigada com águas residuária agroindustriais. Irriga, Botucatu, v. 18, n. 2, p. 243-256, 2013.

LICHTENTHALER, H. K. Chlorophylls and carotenoids: pigments of photosynthetic biomembranes. In: PACKER, L.; DOUCE, R. (Org.). Methods in residuária. London: Academic Press, 1987. p. 350-382.

MARTÍNEZ, S.; SUAY, R.; MORENO, J.; SEGURA, M. L. Reuse of tertiary municipal wastewater effluent for irrigation of Cucumis melo L. Irrigation Science, Berlim, v. 31 , n. 4, p. 661-672, 2013. DOI: $10.1007 / \mathrm{s} 00271-012-$ 0342-4

MEIRELlES, A. F. M.; BALDOTTO, M. A.; BALDOTTO, L. E. B. Produtividade da alface (Lactuca sativa L.) em resposta à aplicação de ácidos húmicos e bactérias diazotróficas, em condições de campo. Revista Ceres, Viçosa, v. 64, n. 5, p. 553-556, 2017.

NASCIMENTO, G. A. S.; SANCHES, A. G.; MOREIRA, E. G. S.; CORDEIRO, C. A. M. Tratamento hidrotérmico na conservação e qualidade pós-colheita de alface. Revista Trópica - Ciências Agrárias e Biológicas, Boa Vista, v. 9, n. 1, p. 65-76, 2017.

OLIVEIRA, J. F.; ALVES, S. M. C.; FERREIRA NETO, M.; BATISTA, R. O. Efeito da água residuária de esgoto doméstico tratado na produção de mudas de pimenta cambuci e quiabo. Enciclopédia Biosfera, Goiânia, v. 8, n. 14, p. 443-452, 2012.

REBOUÇAS, J. R. L.; DIAS, N. S.; GONZAGA, M. I. S.; GHEYI, H. R.; SOUSA NETO, O. N. Crescimento do feijão-caupi irrigado com água residuária de esgoto doméstico tratado. Revista Caatinga, Mossoró, v. 23, n. 1, p. 97-102, 2010.

REIS, H. F.; MELO, C. M.; MELO, E. P.; SILVA, R. A.; SCALON, S. P. Q. Conservação pós-colheita de alface crespa, de cultivo orgânico e convencional, sob atmosfera modificada. Horticultura Brasileira, Brasília, v. 32, n. 3, p. 303-309, 2014. 
RICE, E. W.; BAIRD, R. B.; CLESCERI, A. D. Standard methods for the examination of water and wastewater. 22. ed. Washington: APHA, AWWA, WPCR, 2012. 1496 p.

RODRIGUES, M. B.; BOAS, M. A. V.; SAMPAIO, S. C.; REIS, C. F.; GOMES, S. D. Efeitos de fertirrigações com águas residuária de laticínio e frigorífico no solo e na produtividade da alface. Engenharia Ambiental, Espírito Santo do Pinhal, v. 8, n. 3, p. 173-182, 2011.
SALA, F. C.; COSTA, C. P. Retrospective and trends of Brazilian lettuce crop. Horticultura Brasileira, Brasília, v. 30 , n. 2, p. $187-194,2012$. DOI: 10.1590/S010205362012000200002

WHATELY, M.; CAMPANILI, M. O século da escassez: uma nova cultura de cuidado com a água: impasses e desafios. São Paulo: Claro Enigma, 2016. 23 p. 